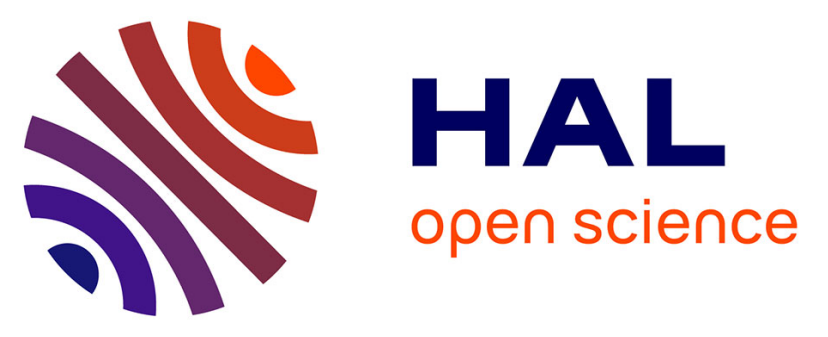

\title{
Assessment of cross-flow filtration as microalgae harvesting technique prior to anaerobic digestion: evaluation of biomass integrity and energy demand
}

Juan B. Giménez, Alberto Bouzas, Hélène Carrère, Jean-Philippe Steyer, José Ferrer, Aurora Seco

\section{To cite this version:}

Juan B. Giménez, Alberto Bouzas, Hélène Carrère, Jean-Philippe Steyer, José Ferrer, et al.. Assessment of cross-flow filtration as microalgae harvesting technique prior to anaerobic digestion: evaluation of biomass integrity and energy demand. Bioresource Technology, 2018, 269, pp.188-194. 10.1016/j.biortech.2018.08.052 . hal-02623290

\section{HAL Id: hal-02623290 \\ https: / hal.inrae.fr/hal-02623290}

Submitted on 26 May 2020

HAL is a multi-disciplinary open access archive for the deposit and dissemination of scientific research documents, whether they are published or not. The documents may come from teaching and research institutions in France or abroad, or from public or private research centers.
L'archive ouverte pluridisciplinaire HAL, est destinée au dépôt et à la diffusion de documents scientifiques de niveau recherche, publiés ou non, émanant des établissements d'enseignement et de recherche français ou étrangers, des laboratoires publics ou privés.

$$
\text { Copyright }
$$




\section{Accepted Manuscript}

Assessment of cross-flow filtration as microalgae harvesting technique prior to anaerobic digestion: evaluation of biomass integrity and energy demand

Juan B. Giménez, Alberto Bouzas, Hélène Carrere, Jean-Philippe Steyer, Jose Ferrer, Aurora Seco

PII:

DOI:

Reference:

To appear in:

Received Date:

Revised Date:

Accepted Date:
S0960-8524(18)31156-8

https://doi.org/10.1016/j.biortech.2018.08.052

BITE 20335

Bioresource Technology

13 June 2018

13 August 2018

14 August 2018

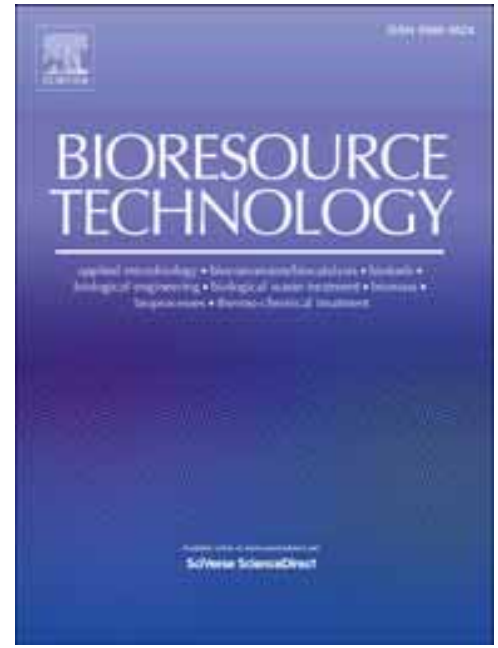

Please cite this article as: Giménez, J.B., Bouzas, A., Carrere, H., Steyer, J-P., Ferrer, J., Seco, A., Assessment of cross-flow filtration as microalgae harvesting technique prior to anaerobic digestion: evaluation of biomass integrity and energy demand, Bioresource Technology (2018), doi: https://doi.org/10.1016/j.biortech.2018.08.052

This is a PDF file of an unedited manuscript that has been accepted for publication. As a service to our customers we are providing this early version of the manuscript. The manuscript will undergo copyediting, typesetting, and review of the resulting proof before it is published in its final form. Please note that during the production process errors may be discovered which could affect the content, and all legal disclaimers that apply to the journal pertain. 


\section{Assessment of cross-flow filtration as microalgae harvesting}

\section{technique prior to anaerobic digestion: evaluation of biomass}

\section{integrity and energy demand.}

Juan B. Giménez ${ }^{\mathrm{a} ;}$; Alberto Bouzas ${ }^{\mathrm{a}}$; Hélène Carrere ${ }^{\mathrm{b}}$; Jean-Philippe Steyer ${ }^{\mathrm{b}}$; Jose Ferrer $^{c}$; Aurora Seco ${ }^{\mathrm{a}}$

a Departament d'Enginyeria Química, Escola Tècnica Superior d’Enginyeria, Universitat de València. Avda. de I’Universitat, s/n. 46100, Burjassot (València), Spain.

${ }^{\mathbf{b}}$ LBE, Univ Montpellier, INRA, 102, avenue des Etangs, 11100 Narbonne, France.

'Institut Universitari d'Investigació d'Enginyeria de l'Aigua i Medi Ambient, IIAMA, Universitat Politècnica de València, Camí de Vera, s/n. 46022, València, Spain.

\section{Abstract}

In the present study, the effect of cross-flow filtration (CFF) on the overall valorization of Chlorella spp. microalgae as biogas was assessed. The effect of CFF on microalgae cell integrity was quantified in terms of viability which was correlated with the anaerobic biodegradability. The viability dropped as the biomass concentration increased, whereas anaerobic biodegradability increased linearly with the viability reduction. It was hypothesized that a stress-induced release and further accumulation of organic polymers during CFF increased the flux resistance which promoted harsher shear-stress conditions. Furthermore, the volume reduction as the concentration increased entailed an increase in the specific energy supply to the biomass. The energy

+ Corresponding author: Tel.: +34 963543 085; e-mail: juan.b.gimenez@uv.es; address: Avda. de la Universitat s/n; 46100, Burjassot (Valencia). Spain. 
demand was positive in the whole range of concentrations studied, yielding an overall energy efficiency as high as $22.9 \%$ for the highest concentration studied. Specifically, heat requirements were lower than electricity requirements only when the biomass concentrations exceeded $10 \mathrm{~g} \mathrm{COD} \cdot \mathrm{L}^{-1}$.

Keywords: harvesting; cross-flow filtration; microalgae integrity; anaerobic biodegradability; energy balance.

\section{INTRODUCTION}

Microalgae biomass is regarded as a promising feedstock for biofuels production, since it has a higher growth yield compared to terrestrial crops (Li et al., 2008) and it can be cultivated in marginal land preventing the competition with food crops for arable land (Singh and Gu, 2010). In addition, microalgae can be grown using wastewater as a water and nutrients source, reporting a double benefit: avoiding intensive use of fertilizers for microalgae growth whilst polishing wastewater (Park et al., 2011). Furthermore, microalgae can capture as much as $1.83 \mathrm{~kg} \mathrm{CO}_{2} \cdot \mathrm{kg}^{-1} \mathrm{VS}$ that can contribute to relieve the global warming (Brennan and Owende, 2010; Lam and Lee, 2012).

In contrast, microalgae cultures usually have low cell density (less than $0.1 \%$ w/v) and concentration up to a certain degree, depending on downstream applications, is generally required. Depending on the final concentration degree achieved, the concentration step can be classified as harvesting (1-7\%) or thickening (7-20 \%) (Pragya et al., 2013). Further dewatering might be required for some applications (e.g. lipids extraction). Unfortunately, microalgae suspensions are very stable due to their negatively charged surface, which hampers the use of gravity sedimentation (Danquah et al., 2009). Indeed, a both economically viable and efficient 
microalgae concentration does not exist so far (Barros et al., 2015). Alternatively, techniques entailing whether an intensive use of reagents (e.g., flocculation, flotation and gravity sedimentation) or energy (e.g., centrifugation or membrane filtration) are normally applied, which can contribute up to one-third to the total microalgae biomass production cost (Estime et al., 2017). Therefore, concentration is regarded as the major bottleneck in the microalgae biomass production process, and still prevents microalgae from being used as feedstock for several purposes (Gross, 2013; Lardon et al., 2009; Singh et al., 2013).

Anaerobic transformation into biogas is a suitable approach for microalgaederived biofuels production, since virtually all the macromolecules in microalgae (lipids, proteins and sugars) can be anaerobically degraded. Unlike lipids extraction process for biodiesel production, biomethane can be produced via wet anaerobic digestion, so concentration of biomass can be avoided. Nevertheless, the concentration of biomass will affect anaerobic digestion in diferent ways. On the one hand, working with dilute cultures entails the handling of large culture-media volumes. Therefore, the required reactor working volume will be proportionally big, since the slow kinetics of anaerobic processes makes high solids retention times necessary (Giménez et al., 2011). The use of a biomass retention system (i.e. physical barriers, reactor configuration) would enable to decouple the hydraulic retention time from the solids retention time, making it possible to treat bigger volumes in smaller reactors, since the high solids concentration achieved can offset the slow kinetics. However, a high amount of energy would still be necessary to warm the biomass up, as long as the digester is operated in the mesophilic or thermophilic range of temperatures whereas microalgae are operated in a lower temperature range $\left(15-25^{\circ} \mathrm{C}\right)$. Additionally, the 
effluent of the anaerobic digestion is, at least, saturated with methane, depending on the mass transfer conditions prevailing within the reactor (Giménez et al., 2012). Methane is both a greenhouse gas (GHG) with a global warming potential over 100 years of 28-36 (IPCC, 2014) and a high heating-value fuel, so both environmental and energetic issues are linked to its free emission to the atmosphere with the effluent. As a powerful GHG, methane must be removed from the effluent. To this regard, dissolved methane recovery with membrane contactors has been proved energetically efficient (Cookney et al., 2016; Crone et al., 2017; Henares et al., 2017), even though a fraction of the potential energy in the dissolved methane has to be devoted to the recovery of the dissolved methane itself. Therefore, the higher the volume to be treated, the higher the energetic loss in the system.

On the other hand, the cell wall of some microalgae is made up of complex carbohydrates which feature high resistance against anaerobic biodegradability (González-Fernández et al., 2013). The anaerobic biodegradability of microalgae is usually hampered by its cell wall, which acts as a protecting barrier that prevents anaerobic microorganisms to reach the inner organic compounds. A number of pretreatment techniques have been developed which are successful at breaking down microalgae cell wall, enabling inner organic compounds to be available to anaerobic organisms (Passos et al., 2014a). There are some literature references (Carrere et al., 2016; Kim et al., 2012; Li et al., 2012) reporting an effect of the biomass concentration on the pretreatment efficiency. In some cases, as in thermal pretreatment, the concentration degree will have a direct effect on the pretreatment cost, since heating less volume will demand less energy. Beyond reducing the pretreatment cost, energyintensive techniques entail the application of a significant amount of mechanical 
energy to the biomass. In these circumstances, the resulting shear-stress could act as a pretreatment itself, enabling in some cases to completely dispense with the pretreatment-related expenses.

In the present study, viability of microalgae was used in order to assess the effect of the cross-flow filtration (CFF), as microalgae biomass concentration technique, over the integrity of microalgae cells, whereas the effect of the concentration step on the overall process was assessed in terms of anaerobic biodegradability. Furthermore, an energy balance was carried out in order to assess the relevance of using the CFF harvesting technique to concentrate microalgae biomass prior to being fed to an anaerobic digester.

\section{MATERIALS AND METHODS}

\subsection{Microalgae biomass source.}

Fresh microalgae mainly consisting of Chlorella spp. (>99\%), were obtained from a pilot scale photobiorreactor (PBR) fed with the nutrient-rich effluent of an anaerobic membrane bioreactor (AnMBR) pilot plant. The PBR were inoculated with microalgae originally collected from the walls of the secondary clarifier in the "Barranco del Carraixet" WWTP (Alboraya, Valencia). Further details on the AnMBR and the PBR pilot plants can be found in (Giménez et al., 2011) and (González-Camejo et al., 2017), respectively. Both pilot plants are property of Calagua research group and are located at the "Barranco del Carraixet" Wastewater Treatment Plant (Valencia, Spain).

\subsection{Experimental Set-Up}


The system consisted of a cross-flow ultrafiltration skid which was directly fed with fresh microalgae. The skid was equipped with a CFF tubular module containing utrafiltration membrane fibres with a molecular weight cut-off of $500 \mathrm{kDa}(\mathrm{KOCH}$ ROMICON $^{\circledR} 2^{\prime \prime}$, Koch membrane technology) and an effective filtration area of $1 \mathrm{~m}^{2}$. The filtration skid also included a centrifugal pump to provide a high flux through the membrane fibres in order to promote the shear conditions necessary to remove the fouling layer from the membrane surface, and a $20 \mathrm{~L}$ buffer tank to feed the pump and to receive the recycled retentate. The system operated at a constant pressure drop through the membrane cartridge of 1.4 bar, yielding a constant permeate flux of 11.3 $\mathrm{L} \cdot \mathrm{m}^{-3} \cdot \mathrm{h}^{-1}$ in the range of concentration tested. A level indicator and a turbidity sensor (TSS) were installed on the buffer tank in order to control the fresh microalgae feeding and to monitor the solids concentration, respectively.

\subsection{Experimental Procedure}

In order to assess the effect of the CFF harvesting technique on the microalgae cell wall integrity, a total of $132 \mathrm{~L}$ of fresh microalgae with an original concentration of $0.691 \mathrm{~g} \mathrm{VS} \cdot \mathrm{L}^{-1}$ were fed to the harvesting system and concentrated up to around $9 \mathrm{~g}$ VS. $\mathrm{L}^{-1}$. This operation mode enabled to operate above the harvesting-system priming volume $(5 \mathrm{~L})$ until the end of the process, yielding a final volume of around $10 \mathrm{~L}$ of concentrated broth. Initially, the harvesting system was continuously topped up with fresh microalgae from the PBR until the VS concentration reached around $3 \mathrm{~g} \mathrm{VS} \cdot \mathrm{L}^{-1}$. Afterwards, the fresh microalgae feeding was stopped and the level of the buffer tank started to decrease as the harvesting remained turned on, until a final concentration of around $9 \mathrm{~g}$ VS $\cdot \mathrm{L}^{-1}$ was achieved. During the operation, 4 different samples of 
microalgae biomass were collected at different times including fresh microalgae from the PBR and the retentate from the buffer tank at around 3, 6 and $9 \mathrm{~g} \mathrm{VS} \cdot \mathrm{L}^{-1}$, that were tagged as $\mathrm{C} 1$, and $\mathrm{C} 2, \mathrm{C} 3$ and $\mathrm{C} 4$, respectively. In addition, permeate samples were collected simultaneously in order to evaluate the retention capacity of the cross-flow ultrafiltration membrane.

\subsection{Analytical Methods.}

The chemical oxygen demand was measured in the total (T-COD) and in the soluble (S-COD) fractions, and in the permeate (P-COD). Soluble fraction was obtained after centrifugation (Eppendorf, 12000xg, 15 minutes). Total and volatile solids, and sulphate concentration were determined according to the Standard Methods (Eaton et al., 2005). Proteins and total sugars were determined in the soluble fraction (S-Pro and $\mathrm{S}-\mathrm{CH}$, respectively) and in the permeate (P-Pro and $\mathrm{P}-\mathrm{CH}$, respectively). A modified Lowry method (Lowry et al., 1951) was used for proteins quantification by using an analytical kit commercialised by Sigma-Aldrich, whereas total sugars were determined according to the Dubois method (DuBois et al., 1956).

\subsection{Cell viability}

Cell viability assays were performed in duplicate using SYTOX Green DNA

staining dye (Invitrogen S7020). $0.1 \mu \mathrm{L}$ of SYTOX Green $5 \mathrm{mM}$ was added to $50 \mu \mathrm{L}$ of 250-400 mg. $\mathrm{L}^{-1}$ suspended solids concentration of microalgae culture. As the SYTOX Green is light-sensitive, the samples were incubated in the dark during 5 minutes. Samples were excited using a fluorescence microscope (DM2500, Leica, Germany) equipped with a filter set at $450-490 \mathrm{~nm}$ and $515 \mathrm{~nm}$ for excitation and emission, 
respectively. More than 200 cells were counted for viability calculation in a Neubauer counting chamber for each experiment.

\subsection{Biomethane potential tests}

Biodegradability of microalgae biomass was assessed in terms of biomethane potential, considering that the theoretical specific methane potential per gram of COD is $350 \mathrm{STP} \mathrm{mL} \mathrm{CH}_{4}$. Biomethane potential tests were carried out in triplicate for each sample using an Automated Methane Potential Test System (AMPTS II, BioProcess Control, Sweden) at $35^{\circ} \mathrm{C}$. The organic load added to each bottle was exactly the same ( $0.68 \mathrm{~g}$ COD), regardless of the microalgae biomass concentration and was calculated on the basis of the less concentrated microalgae biomass sample, by adjusting the total volume of the experiment to 1 litre and setting an inoculum to substrate ratio (I/S) of 2. In order to add the same organic load to each bottle, the volume of microalgae biomass added varied depending on the concentration of each microalgae biomass sample. Samples were seeded with anaerobic sludge coming from an industrial anaerobic digester treating municipal sewage from the "Barranco del Carraixet" WWTP in Alboraya, Valencia. Furthermore, nutrients and trace elements, and phosphate buffer were added in order to avoid growth limitation and inhibition by acidification, respectively. The nutrient stock solution consisted of $\left(\mathrm{g} \cdot \mathrm{L}^{-1}\right): \mathrm{NH}_{4} \mathrm{Cl}(170)$, $\mathrm{CaCl}_{2} \cdot 2 \mathrm{H}_{2} \mathrm{O}(8), \mathrm{MgSO}_{4} \cdot 7 \mathrm{H}_{2} \mathrm{O}(9)$ and the trace element stock solution contained $\left(\mathrm{g} \cdot \mathrm{L}^{-1}\right)$ : $\mathrm{FeCl}_{3} \cdot 4 \mathrm{H}_{2} \mathrm{O}(2), \mathrm{CoCl}_{2} \cdot 6 \mathrm{H}_{2} \mathrm{O}(2), \mathrm{MnCl}_{2} \cdot 4 \mathrm{H}_{2} \mathrm{O}(0.5), \mathrm{CuCl}_{2} \cdot 2 \mathrm{H}_{2} \mathrm{O}(30), \mathrm{ZnCl}_{2}(50), \mathrm{H}_{3} \mathrm{BO}_{3}$ (50), $\left(\mathrm{NH}_{4}\right)_{6} \mathrm{Mo}_{7} \mathrm{O}_{2} \cdot 4 \mathrm{H}_{2} \mathrm{O}(90), \mathrm{Na}_{2} \mathrm{SeO}_{3} \cdot 5 \mathrm{H}_{2} \mathrm{O}$ (100), $\mathrm{NiCl}_{2} \cdot 6 \mathrm{H}_{2} \mathrm{O}$ (50), EDTA (1), $\mathrm{HCl} 36 \%$

$\left(1 \mathrm{ml} . \mathrm{L}^{-1}\right)$, Resazurine (0.5). The $\mathrm{pH}$ buffer stock solution was composed of $\mathrm{K}_{2} \mathrm{HPO}_{4} \cdot 3 \mathrm{H}_{2} \mathrm{O}\left(45.65 \mathrm{~g} . \mathrm{L}^{-1}\right)$ and $\mathrm{NaH}_{2} \mathrm{PO}_{4} \cdot 2 \mathrm{H}_{2} \mathrm{O}\left(31.20 \mathrm{~g} . \mathrm{L}^{-1}\right) .6 \mathrm{~mL}$ of nutrient solution, 
$0.6 \mathrm{~mL}$ of trace elements solution and $50 \mathrm{~mL}$ of buffer solution per litre of microalgae biomass were dosed to each sample .

\section{RESULTS AND DISCUSSION}

\subsection{Microalgae biomass viability \& Biodegradability.}

In the present study, the effect of CFF harvesting technique on microalgae cell wall integrity was evaluated in terms of viability and biodegradability. To do so, microalgae biomass samples with different concentration degrees (C1 to $\mathrm{C} 4)$ were collected at different times during harvesting. Table 1 shows the average characterisation of the different microalgae biomass samples used in the present study. Standard deviation (SD) of triplicates is also shown.

Viability revealed that the CFF harvesting equipment used in the present study had a clear effect on the microalgae cell-wall integrity, since the viability decreased from $89,0 \%(C 1)$ to $38,1 \%(C 4)$.

In addition, a good linear positive correlation $\left(R^{2}=0,9747\right)$ was found between the non-viable cells percentage $([1-V] \%)$ and the biodegradability (BD \%) of the different samples, evidencing that the biodegradability of microalgae biomass was dependent on the cell-wall integrity. The data were adjusted by a least squares regression analysis to the Equation 1:

$$
B D \%=0.8196 \cdot[1-V] \%+2.9542
$$
Equation 1

(Prajapati et al., 2014) suggested in their study regarding anaerobic biodegradability of different Chlorella species (i.e. chlorella minutissima, pyrenoidosa and vulgaris), that some microalgae cells might had been broken during overnight gravity settling, since they observed an unusually high initial methane production in the BMP experiments that resulted in anaerobic biodegradabilities between 22.8 to 
$31.9 \%$. However, microalgae cell-integrity data, both before and after the harvesting step, were not furnished in this study. Neither did the authors provide the biomass concentration degree achieved with gravity settling as harvesting method. (Mahdy et al., 2014) reported a biodegradability value of $54 \%$ for fresh chlorella vulgaris biomass after being concentrated up to $22.3 \mathrm{~g} \mathrm{COD} \cdot \mathrm{L}^{-1}$ by centrifugation at $5000 \mathrm{rpm}$ during 15 minutes. The authors agreed that this biodegradability value was higher than other values reported in literature, although they did not hypothesized about a possible explanation to this unexpected result. Also (Mendez et al., 2013) reported a biodegradability value of $39.7 \%$ for Chlorella vulgaris biomass concentrated up to 24.9 g COD $\cdot \mathrm{L}^{-1}$, although the authors did not provide any details about the harvesting technique used.

The lack of homogeneity in literature regarding the anaerobic biodegradability values for fresh Chlorella vulgaris biomass states that microalgae final biodegradability not only depends on its composition and the pretreatment used, but there might also be a contribution from the harvesting step. This underlying effect of the harvesting step on the final biodegradability might be related to the effect of the technique used on the integrity of the cell wall and on the stress induced over microalgae. Therefore, in the light of these results, harvesting should be considered as a pretreatment itself enabling, in some cases, to dispense with subsequent expensive pretreatments to break the cell-wall.

In contrast, the COD mass balance stated that organic matter solubilisation was not linked to neither viability nor biodegradability. Thus, generation of soluble organic matter accounting for a 1.18-fold increase in the S-COD/T-COD ratio only took place from C1 to C2 (see Table 2), i.e. as long as fresh algae were fed to the harvesting 
system. The further increase in S-COD concentration in C3 and C4 (see Table 1) was explained by the sole accumulation of the S-COD already present in the system. No generation was observed indicating that, unlike biodegradability, solubilisation of organic matter was not related to cell-wall disruption. Alternatively, it is hypothesized that solubilisation took place as a response to the more stressful conditions prevailing on the harvesting system, that promoted the release of soluble microbial products (SMP) likely as a protection/survival strategy which contributed to increase the S-COD. Extracellular polymeric substances (EPS) were not measured in the fresh microalgae culture. Therefore, the origin of the SMP (whether it was EPS or intracellular compounds being released following the cell-wall disruption) is not clear. In any case, these SMP built up within the system due to the high retention capacity of the ultrafiltration membranes, as evidenced by the steadiness of the COD and proteins concentrations in the permeate (see Table 1 ) in spite of their accumulation in the retentate, resulting in retention efficiencies of $98,4 \%$ and $92,8 \%$, respectively. Results regarding total sugars concentration in the supernantant of the centrifuged samples were controversial, since the value was higher than the COD concentration (data not shown). This error was attributed to the complex matrix of the supernatant which interferred in the colorimetric determination.

This hypothesis is also supported by the S-COD fraction associated to the proteins in the soluble phase $\left(\mathrm{S}-\mathrm{COD}_{\mathrm{Pro}} / \mathrm{S}-\mathrm{COD}\right.$; a COD/Proteins ratio of $2.43 \mathrm{~g}$ COD $\cdot \mathrm{g}^{-1}$ VS has been considered (Sialve et al., 2009).In spite of an initial decrease, S-COD Pro/SCOD finally reached a similar value to that of the fresh sample (see Table 2), indicating

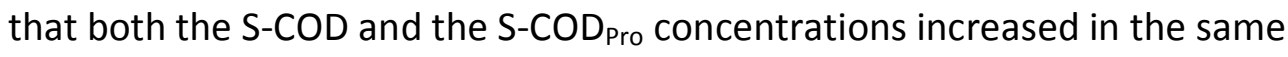
proportion. Accordingly, the concentration factors achieved for the COD ( $\left.F_{C O D}\right)$ in the 
supernatant of the different centrifuged samples, with regard to the fresh microalgae culture (C1), were similar to those achieved for proteins $\left(F_{P R O}\right)$. Total sugars concentration factors $\left(\mathrm{F}_{\mathrm{CH}}\right)$ were also calculated in spite of the controversial results obtained for the total sugars absolute concentration values. $\mathrm{F}_{\mathrm{CH}}$ were slightly higher than $\mathrm{F}_{\mathrm{COD}}$ and $\mathrm{F}_{\mathrm{PRO}}$, suggesting that the accumulation of sugars within the system followed a similar trend to that of proteins.

These results state that the microalgae cell-wall breakage was enough to enable anaerobic microorganism to access and degrade the inner organic compounds of the former, even though these inner compounds were not completely released into the broth. Presumably, cell-wall breakage yielded microalgae cells permeable to anaerobic microorganisms, which were able to get into the microalgae and degrade some biodegradable compounds that were not accessible in intact cells. Anaerobic microorganisms invading microalgae cells rather than microalgae inner compounds being released to the broth can be proposed as a more suitable hypothesis since, as stated previously, S-COD generation only took place from C1 to C2, whereas biodegradability was strongly correlated with the percentage of non-viable microalgae cells.

Both the viability and the biodegradability trends, regarding the concentration time or degree, were non-linear (see Table 1). In both cases, the higher increase from $\mathrm{C} 3$ to $\mathrm{C} 4$ than from $\mathrm{C} 1$ to $\mathrm{C} 2$ or from $\mathrm{C} 2$ to $\mathrm{C} 3$ evidenced a higher impact of the CFF harvesting technique over both the viability and the biodegradability percentages of the microalgae biomass as the concentration rose. Two major contributors to the observed trend were identified. On the one hand, it was hypothesized that the increase in the S-COD was related to an initial release and further concentration of 
SMP. Thus, the increase in the SMP concentration led to an increase in the viscosity of the sample which promoted harsher shear-stress conditions as a result of the higher flow resistance through the centrifugal pump and/or through the cross-flow ultrafiltration membrane.

In this regard, (Scarsella et al., 2012) studied the effect of the mechanical stress produced by several kinds of pumps on microalgae biomass integrity. According to these authors, culture circulation establishes a shear field whose effect may vary from beneficial to deleterious, according to the shear sensitivity, which depends on the microalgae strain, the shear regime and the environmental conditions. They found that centrifugal pumps have a significant impact on the microalgae integrity. Specifically, microalgae Chlorella vulgaris appeared to be weaker than Scendesmus dimorphus as evidenced by an optical density reduction in the case of the former, following the application of a similar mechanical stress. Specific photosynthetic activity remained constant, indicating that surviving cells preserved their activity.

On the other hand, the specific power supply per unit of volume of the concentrated microalgae suspension increased as the volume decreased, since the number of passes through the harvesting system increased from 1 pass every 5 minutes to 3 passes per minute, inducing a higher mechanical stress over the microalgae biomass. Accordingly, (Alías et al., 2004) gathered results from the diatom Pheadactlylum tricornutum circulating through different pumps. The authors found a higher decay in biomass concentration and in the ratio of the maximum photosystem II quantum yield when cultures were circulated with centrifugal pumps. They observed that damage to cells increased with both the shear rate in the impeller and the increase of the number of passes through the cavity pump. 
As well as reducing the viability and increasing the biodegradability of microalgae biomass, there are several effects related to biomass concentration using CFF that should be taken into account when assessing continuous anaerobic digestion of microalgae. First of all, concentrating the microalgae biomass would entail a reduction in the daily flow-rate to the digester whilst keeping the organic load constant. Furthermore, and since sulphate is a soluble compound present in the culture coming from the PBR (González-Camejo et al., 2017), the sulphate load to the anaerobic digester would be reduced, resulting in an increased COD to sulphate ratio. Dissimilatory sulphate reduction to sulphide is carried out by sulphate reducing bacteria (SRB) which perform anaerobic respiration rather than fermentation. Stoichiometrically, 2 grams of COD are consumed by SRB in order to dissimilatory reduce one gram of sulphur. Respiration, even using sulphate as electron acceptor, is more efficient than fermentation, which enables SRB to outcompete methanogenic archaea (MA) both from kinetic and thermodynamical points of view (Lens et al., 1998). Therefore, the biodegradable COD would preferentially be consumed by SRB rather than $\mathrm{MA}$, for $\mathrm{COD} / \mathrm{S}-\mathrm{SO}_{4}$ ratios below 2 .

For $\mathrm{COD} / \mathrm{S}-\mathrm{SO}_{4}$ ratios of 2 and above, there would theoretically be enough $\mathrm{COD}$ to reduce all sulphate, enabling MA to consume the leftover biodegradable COD that would alternatively end-up as methane. In the present study, methane production will start at a microalgae biomass concentration above $0.116 \%(\mathrm{w} / \mathrm{v})$.

In the present study, the methane production from the fresh microalgae biomass resulted in a biodegradability of $9.3 \%$, even though the $\mathrm{COD} / \mathrm{S}-\mathrm{SO}_{4}$ ratio was lower than 2. It was hypothesized that the use of an inoculum with a virtually inexistent sulphidogenic activity allowed the MA to take advantage of the COD present 
before a well-stablished SRB community was developed (Giménez et al., 2011).

However, this behaviour diverts from what it could be expected in continuous digesters, where SRB would outcompete MA (Giménez et al., 2011; Lens et al., 1998).

In addition, methane is produced by MA within the liquid face. Methane diffuses through the liquid bulk and is further distributed between both the liquid and gas phases until the equilibrium is reached. The solubility equilibrium of a gas in a liquid is governed by the Henry's law. Therefore, the dissolved methane concentration can be calculated by means of the equilibrium law as the saturation concentration as long as there is a good mass transfer between both liquid and gas phases. If the system is not properly mixed and the mass transfer is deficient, the liquid phase will probably be oversaturated with methane. As a result, the lower the volume to be treated, the lower the methane loss with the effluent, regardless of the total methane production.

Figure 1 shows the influent biodegradable COD fate depending on the biomass concentration achieved during the harvesting step. The contribution of the influent biodegradable COD to the different sinks have been calculated according to the previously exposed premises (details on how to quantify each contribution will be given in section "3.2 Energy Considerations.", Equations (5 to 9). Briefly, biodegradable COD will preferentially be consumed by SRB (COD-SRB), as long as sulphate is present. It has been assumed that all sulphate will be reduced by SRB, entailing a COD consumption of $2 \mathrm{~g}$ COD $\cdot \mathrm{g}^{-1} \mathrm{~S}$ (Lens et al., 1998). The remaining biodegradable COD will be available for MA, which will be transformed into methane. A fraction of the produced methane will remain dissolved in the liquid (COD-DCH4) according to Henry's equilibrium law. In order to calculate the dissolved methane, a methane fraction in the biogas of 0.67 is assumed as a typical value (Passos et al., 2014b). 
Finally, the remaining fraction of the produced methane will end up in the biogas (COD-BG CH4). As it can be seen, for the raw biomass (C1), the influent biodegradable COD is completely consumed by SRB (COD-SRB), whereas for the most concentrated sample (C4), $98.1 \%$ of the biodegradable influent COD is devoted to methane production by MA. A small fraction of the methane produced $(0.8 \%)$ remains dissolved (COD-DCH4), and the rest is recovered with the biogas (COD-BGCH4).

\subsection{Energy Considerations.}

An energy balance was carried out to assess the interest of using the CFF harvesting technique to concentrate microalgae biomass prior to being fed to an anaerobic digester. The following assumptions were made in order to perform the energy balance:

- Neither microalgae biomass growth nor anaerobic digestion energetic requirements (namely mixing and pumping, and aeration when applicable) were considered in this study.

- All the biogas produced is fuelled to a CHP system. A microturbine was selected as CHP system which features electric and thermal efficiencies of 26.7 and 41.1 \%, respectively (U.S Department of Energy Fact sheet series, n.d.).

- Thermal energy production is devoted to warm the microalgae biomass up to mesophilic conditions (i.e. $35 \stackrel{\circ}{\circ}$ ) prior to being fed to the anaerobic digester. The density and specific heat of microalgae biomass were supposed to be the same as those of water. Heat loss through the anaerobic digester wall was considered (heat-loss through neither top nor bottom have been considered (Passos and Ferrer, 2014)). Anaerobic digester was assumed to have cylindrical 
geometry with a diameter to height ratio of 2:1. Digester dimensions were determined based on the useful volume for a HRT of 20 days.

- All calculations were made on the basis of a daily microalgae biomass production of $1 \mathrm{~m}^{3}$.

Thermal energy requirements $\left(E_{i, T}\right)$ were calculated as the addition of the energy required to warm the microalgae biomass up to mesophilic conditions and the energy loss through the digester wall according to equation (1), whereas electric energy requirements $\left(E_{i, E}\right)$ only accounted for the electric energy demand from the harvesting unit (equation (2)):

$$
\begin{array}{cc}
E_{i, T}(M J / d)=\rho \cdot Q \cdot \gamma \cdot\left(T_{d}-T_{a}\right)+k \cdot A \cdot\left(T_{d}-T_{a}\right) \cdot 86.4 & \text { Equation (2) } \\
E_{i, E}(M J / d)=E_{\text {cons }, C F F} \cdot Q & \text { Equation (3) }
\end{array}
$$

Specific energy consumption data in a CFF unit $\left(E_{\text {cons,CFF }}\right)$ reported by (Danquah et al., 2009) have been used in the present work. These authors reported a net energy consumption of $7.42 \mathrm{MJ} \cdot \mathrm{m}^{-3}$ of permeate for a CFF unit which consisted in a 4 GPM Pellicon cassette system (Millipore, DUOBLOC TM, USA), harvesting Tetraselmis suecica.

Moreover, both electric $\left(E_{O, E}\right)$ and thermal $\left(E_{O, T}\right)$ energy productions were calculated from the daily methane production recovered with the biogas $\left(P_{B G}^{C H_{4}}\right)$ and the electric and thermal efficiencies of the CHP unit selected, respectively (see Equations (3) and (4)).

$$
\begin{array}{ll}
E_{o, E}(\mathrm{MJ} / d)=P_{B G}^{\mathrm{CH}_{4}} \cdot \xi^{\mathrm{CH}_{4}} \cdot \eta_{C H P}^{\text {Electric }} & \text { Equation (4) } \\
E_{o, T}(\mathrm{MJ} / \mathrm{d})=P_{B G}^{\mathrm{CH}_{4}} \cdot \xi^{\mathrm{CH}_{4}} \cdot \eta_{C H P}^{\text {Thermal }} & \text { Equation (5) }
\end{array}
$$

A lower heating value of $35.8 \mathrm{MJ} \cdot \mathrm{m}^{-3}$ for the methane was considered for the calculations (Tchobanoglous and Burton, 1998). 
Total methane production was calculated from the total amount of COD

available for methanogens, by subtracting the COD consumed by SRB to the total biodegradable COD, according to Equation (5):

$$
P_{T}^{C_{4}}\left(m^{3} C_{4} S T P / d\right)=\left([C O D]_{0} \cdot \% B D-2 \cdot\left[S-S_{4}\right]\right) \cdot Q \cdot Y_{\text {Theo }}^{C H_{4}} \quad \text { Equation (6) }
$$

where $\% \mathrm{BD}$ is the percentage of biodegradability of the microalgae biomass

interpolated from the values previously reported and $\mathrm{S}^{-} \mathrm{SO}_{4}$ is the sulphur

concentration as sulphate $\left(\mathrm{kg} \mathrm{S} \cdot \mathrm{m}^{-3}\right)$. The factor multiplying sulphate concentration

term accounts for the stoichiometric amount of COD consumed to reduce sulphate (Lens et al., 1998).

Dissolved methane was excluded from the total methane production for the energy output calculation (see Equation (6)). However, a deeper insight into the energy balance of dissolved methane recovery process is necessary to elucidate whether the biological oxidation of dissolved methane, just to prevent its emission, would be a more suitable option.

$$
P_{B G}^{C H_{4}}\left(m^{3} C_{4} S T P / d\right)=P_{T}^{C H_{4}}-P_{D}^{C H_{4}} \quad \text { Equation (7) }
$$

For the dissolved methane estimation (see equations (7) to (9)), it was assumed that the solubility of methane in the effluent of the digester was similar to that of pure water. Also, a methane fraction of 0.67 was selected for the gas phase.

$$
\begin{array}{cc}
P_{D}^{\mathrm{CH}_{4}}\left(\mathrm{~m}^{3} \mathrm{CH}_{4} S T P / d\right)=Q \cdot \frac{x^{\mathrm{CH}_{4}} \cdot M^{W}}{\left(1-x^{C H_{4}}\right)} \cdot R \cdot T & \text { Equation (8) } \\
P \cdot y^{\mathrm{CH}_{4}}=H^{C H_{4}}(T) \cdot x^{C H_{4}} & \text { Equation (9) } \\
H^{C H_{4}}(T)=10^{\left[\frac{-675.74}{T(K)}+6.88\right]} & \text { Equation (10) }
\end{array}
$$

where $x^{\mathrm{CH}_{4}}$ and $y^{\mathrm{CH}_{4}}$ stand for the molar fraction of methane in the liquid and in the gas phases, respectively. $M^{W}$ stands for the molarity of water $\left(55.5 \mathrm{kmol} \cdot \mathrm{m}^{-3}\right), R$ 
$\left(0.082057 \mathrm{~m}^{3} \cdot \mathrm{atm} \cdot \mathrm{K}^{-1} \cdot \mathrm{kmol}^{-1}\right)$ stands for the universal constant of ideal gases, $P($ atm $)$ stands for pressure and $H^{C_{4}}(T)\left(a^{-1}\right)$ stands for the temperature-dependent Henry's constant for methane (Tchobanoglous and Burton, 1998).

The electric and thermal energy balances were assessed in terms of the net electric and thermal energy demands (NEED and NTED, respectively) according to Equations (10) and (11), which were calculated in the basis of the electric and thermal energy inputs (see Equations (1) and (2)) and outputs (see Equations (8) and (9)) previously described. Furthermore, the total net energy demand (NED), was calculated as the addition of both the net electric and thermal energy demands (see Equation (12)).

$$
\begin{array}{ll}
\operatorname{NEED}(M J / d)=E_{i, E}(M J / d)-E_{o, E}(M J / d) & \text { Equation (11) } \\
\operatorname{NTED}(M J / d)=E_{i, T}(M J / d)-E_{o, T}(M J / d) & \text { Equation (12) } \\
N E D(M J / d)=N E E D(M J / d)+N T E D(M J / d) & \text { Equation (13) }
\end{array}
$$

Figure 2 (a) shows that the electric energy requirements increase as the microalgae concentration increases, as a result of the increase in the volume to be filtered. On the contrary, the electric energy production increases as the biodegradability and the availability of COD to the MA increases, as a result of a higher methane production, bringing about a decrease in the NEED for a microalgae biomass COD concentration higher than $1 \%(w / v)$. Figure $5(b)$ shows that the thermal energy requirements decrease significantly as the microalgae concentration increases, since the volume to be warmed up is lower. Furthermore, the higher methane production increases the thermal energy production, both contributing to decrease the NTED. Figure 5 (c) shows that in spite of the increase in the NEED for biomass COD concentrations lower than $1 \%(w / v)$, its contribution to the NED is not really 
significant, as compared to the NTED contribution. As a result, the NED decreases with the biomass COD concentration, and this decrease is more pronounced for biomass COD concentrations higher than $1 \%(\mathrm{w} / \mathrm{v})$. Nonetheless, the NED remained positive in the whole range of concentrations evaluated, corresponding the lowest NED value to the most concentrated sample (C4), that accounted for $11.9 \mathrm{MJ} \cdot \mathrm{m}^{-3}$.

Electric and thermal efficiencies were defined as the electric and thermal energy production to consumption ratio $\left(E_{o} / E_{i}\right)$, respectively. As shown in Figure 3 , the highest electric and thermal efficiencies correspond to the most concentrated sample, accounting for 20.1 and $25.2 \%$, respectively, yielding an overall energetic efficiency of $22.9 \%$. It is worth to mention that, in the present study, a threshold concentration value at around $1 \%$ was observed, above which the thermal efficiency was higher than the electric efficiency.

\section{CONCLUSIONS}

The effect of cross-flow filtration over microalgae integrity was evaluated in terms of cell viability and biodegradability. The concentration achieved affected both viability and biodegradability of biomass, which were linearly correlated. It was hypothesized that the accumulation of organic polymers during the harvesting promoted harsher shear-stress conditions. Furthermore, the specific energy supply increased as the total volume decreased. The energy demand turned out to be positive in the whole range of concentrations evaluated. The lowest energy demand corresponded to the most concentrated sample and accounted for $11.9 \mathrm{MJ} \cdot \mathrm{m}^{-3}$, yielding and an energetic efficiency of $22.9 \%$.

\section{APPENDIX A: SUPPLEMENTARY DATA}


E-supplementary data for this work can be found in e-version of this paper

online

\section{ACKNOWLEDGEMENTS}

This work was funded by the Spanish Ministry of Economy and Competitiveness with the support from the European Commission through the European Regional Development Funds (MINECO, CTM2011-28595-C02-01 and CTM2011-28595-C02-02), which are gratefully acknowledged. The authors would also express their gratitude to the Education, Investigation, Culture and Sports Council from the Valencian Generality for the Post-Doctoral fellowship awarded to Juan Bautista Giménez Garcia (APOSTD/2016/104).

\section{REFERENCES}

1. Alías, C.B., García-Malea López, M.C., Acién Fernández, F.G., Fernández Sevilla, J.M., García Sánchez, J.L., Molina Grima, E., 2004. Influence of power supply in the feasibility of Phaeodactylum tricornutum cultures. Biotechnol. Bioeng. 87, 723-733. https://doi.org/10.1002/bit.20179

2. Barros, A.I., Gonçalves, A.L., Simões, M., Pires, J.C.M., 2015. Harvesting techniques applied to microalgae : A review 41, 1489-1500. https://doi.org/10.1016/j.rser.2014.09.037

3. Brennan, L., Owende, P., 2010. Biofuels from microalgae-A review of technologies for production, processing, and extractions of biofuels and coproducts. Renew. Sustain. Energy Rev. 14, 557-577. https://doi.org/10.1016/j.rser.2009.10.009

4. Carrere, H., Antonopoulou, G., Affes, R., Passos, F., Battimelli, A., Lyberatos, G., Ferrer, I., 2016. Review of feedstock pretreatment strategies for improved 
anaerobic digestion: From lab-scale research to full-scale application.

Bioresour. Technol. 199, 386-397.

https://doi.org/10.1016/j.biortech.2015.09.007

5. Cookney, J., Mcleod, A., Mathioudakis, V., Ncube, P., Soares, A., Jefferson, B., McAdam, E.J., 2016. Dissolved methane recovery from anaerobic effluents using hollow fibre membrane contactors. J. Memb. Sci. 502, 141-150. https://doi.org/10.1016/j.memsci.2015.12.037

6. Crone, B.C., Garland, J.L., Sorial, G.A., Vane, L.M., 2017. Corrigendum to "Significance of dissolved methane in effluents of anaerobically treated low strength wastewater and potential for recovery as an energy product: A review" [Water Res. 104 (2016) 520531](S0043135416306194)(10.1016/j.watres.2016.08.019). Water Res. 111, 420. https://doi.org/10.1016/j.watres.2017.01.035

7. Danquah, M.K., Ang, L., Uduman, N., Moheimani, N., Forde, G.M., 2009. Dewatering of microalgal culture for biodiesel production: Exploring polymer flocculation and tangential flow filtration. J. Chem. Technol. Biotechnol. 84, 1078-1083. https://doi.org/10.1002/jctb.2137

8. DuBois, M., Gilles, K.A., Hamilton, J.K., Rebers, P.A., Smith, F., 1956. Colorimetric Method for Determination of Sugars and Related Substances. Anal. Chem. 28, 350-356. https://doi.org/10.1021/ac60111a017

9. Eaton, A.D., Clesceri, L.S., Rice, E.W., Greenberg, A.E. (Eds.), 2005. Standard methods for the examination of water \& wastewater, 21st ed. Ammerican Public Health Association, Washington.

10. Estime, B., Ren, D., Sureshkumar, R., 2017. Cultivation and energy efficient 
harvesting of microalgae using thermoreversible sol-gel transition. Sci. Rep. 7, 40725. https://doi.org/10.1038/srep40725

11. Giménez, J.B., Martí, N., Ferrer, J., Seco, A., 2012. Methane recovery efficiency in a submerged anaerobic membrane bioreactor (SAnMBR) treating sulphaterich urban wastewater: Evaluation of methane losses with the effluent.

Bioresour. Technol. 118, 67-72. https://doi.org/10.1016/j.biortech.2012.05.019

12. Giménez, J.B., Robles, A., Carretero, L., Durán, F., Ruano, M. V, Gatti, M.N., Ribes, J., Ferrer, J., Seco, A., 2011. Experimental study of the anaerobic urban wastewater treatment in a submerged hollow-fibre membrane bioreactor at pilot scale. Bioresour. Technol. 102, 8799-806.

https://doi.org/10.1016/j.biortech.2011.07.014

13. González-Camejo, J., Serna-García, R., Viruela, A., Pachés, M., Durán, F., Robles, A., Ruano, M.V., Barat, R., Seco, A., 2017. Short and long-term experiments on the effect of sulphide on microalgae cultivation in tertiary sewage treatment. Bioresour. Technol. 244, 15-22. https://doi.org/10.1016/j.biortech.2017.07.126

14. González-Fernández, C., Sialve, B., Bernet, N., Steyer, J.P., 2013. Effect of organic loading rate on anaerobic digestion of thermally pretreated Scenedesmus sp. biomass. Bioresour. Technol. 129, 219-223. https://doi.org/10.1016/j.biortech.2012.10.123

15. Gross, M.A., 2013. Development and optimization of algal cultivation systems. lowa State University.

16. Henares, M., Izquierdo, M., Marzal, P., Martínez-Soria, V., 2017. Demethanization of aqueous anaerobic effluents using a polydimethylsiloxane membrane module: Mass transfer, fouling and energy analysis. Sep. Purif. 
Technol. 186, 10-19. https://doi.org/10.1016/j.seppur.2017.05.035

17. IPCC, 2014. CLIMATE CHANGE 2013: The Physical Science Basis. Working Group I contribution to the fifth assessment report of the Intergovernmental Panel on Climate Change, 5th A.R. ed. Cambridge University Press, New York (USA). https://doi.org/10.1017/CBO9781107415324

18. Kim, J.K., Um, B.H., Kim, T.H., 2012. Bioethanol production from micro-algae, Schizocytrium sp., using hydrothermal treatment and biological conversion. Korean J. Chem. Eng. 29, 209-214. https://doi.org/10.1007/s11814-011-0169-3

19. Lam, M.K., Lee, K.T., 2012. Microalgae biofuels: A critical review of issues, problems and the way forward. Biotechnol. Adv. 30, 673-690. https://doi.org/10.1016/j.biotechadv.2011.11.008

20. Lardon, L., Hélias, A., Sialve, B., Steyer, J.P., Bernard, O., 2009. Life-Cycle Assessment of Biodiesel Production from Microalgae. Environ. Sci. Technol. 43, 6475-6481. https://doi.org/http://dx.doi.org/10.1021/es900705j

21. Lens, P.N.L., Visser, a., Janssen, a. J.H., Pol, L.W.H., Lettinga, G., 1998. Biotechnological Treatment of Sulfate-Rich Wastewaters. Crit. Rev. Environ. Sci. Technol. 28, 41-88. https://doi.org/10.1080/10643389891254160

22. Li, S., Zhang, H., Han, D., Row, K.H., 2012. Optimization of enzymatic extraction of polysaccharides from some marine algae by response surface methodology. Korean J. Chem. Eng. 29, 650-656. https://doi.org/10.1007/s11814-011-0221-3

23. Li, Y., Horsman, M., Nan, W., Lan, C.Q., Dubois-Calero, N., 2008. Biofuels from microalgae. Biotechnol. Prog. 1, 815-820. https://doi.org/10.1021/bp.070371k

24. Lowry, O.H., Rosebrough, N.J., Farr, A.L., Randall, R.J., 1951. Protein measurement with the folin phenol reagent. J. Biol. Chem. 193, 265-275. 
25. Mahdy, A., Mendez, L., Ballesteros, M., González-Fernández, C., 2014.

Enhanced methane production of Chlorella vulgaris and Chlamydomonas reinhardtii by hydrolytic enzymes addition. Energy Convers. Manag. 85, 551557. https://doi.org/10.1016/j.enconman.2014.04.097

26. Mendez, L., Mahdy, A., Timmers, R.A., Ballesteros, M., González-Fernández, C., 2013. Enhancing methane production of Chlorella vulgaris via thermochemical pretreatments. Bioresour. Technol. 149, 136-141. https://doi.org/10.1016/j.biortech.2013.08.136

27. Park, J.B.K., Craggs, R.J., Shilton, A.N., 2011. Wastewater treatment high rate algal ponds for biofuel production. Bioresour. Technol. 102, 35-42. https://doi.org/10.1016/j.biortech.2010.06.158

28. Passos, F., Ferrer, I., 2014. Microalgae Conversion to Biogas: Thermal Pretreatment Contribution on Net Energy Production. Environ. Sci. Technol. 48, 7171-7178. https://doi.org/10.1021/es500982v

29. Passos, F., Uggetti, E., Carr??re, H., Ferrer, I., 2014a. Pretreatment of microalgae to improve biogas production: A review. Bioresour. Technol. 172, 403-412. https://doi.org/10.1016/j.biortech.2014.08.114

30. Passos, F., Uggetti, E., Carrère, H., Ferrer, I., 2014b. Algal Biomass: Physical Pretreatments. Physical Pretreatments., Pretreatment of Biomass: Processes and Technologies. https://doi.org/10.1016/B978-0-12-800080-9.00011-6

31. Pragya, N., Pandey, K.K., Sahoo, P.K., 2013. A review on harvesting, oil extraction and biofuels production technologies from microalgae. Renew. Sustain. Energy Rev. 24, 159-171. https://doi.org/10.1016/j.rser.2013.03.034

32. Prajapati, S.K., Malik, A., Vijay, V.K., 2014. Comparative evaluation of biomass 
production and bioenergy generation potential of Chlorella spp. through anaerobic digestion. Appl. Energy 114, 790-797. https://doi.org/10.1016/j.apenergy.2013.08.021

33. Scarsella, M., Torzillo, G., Cicci, A., Belotti, G., De Filippis, P., Bravi, M., 2012. Mechanical stress tolerance of two microalgae. Process Biochem. 47, 16031611. https://doi.org/10.1016/j.procbio.2011.07.002

34. Sialve, B., Bernet, N., Bernard, O., 2009. Anaerobic digestion of microalgae as a necesary step to make microalgae biodiesel sustainable. Biotechnol. Adv. 27, 409-416. https://doi.org/10.1016/j.biotechadv.2009.03.001

35. Singh, J., Gu, S., 2010. Commercialization potential of microalgae for biofuels production. Renew. Sustain. Energy Rev. 14, 2596-2610. https://doi.org/10.1016/j.rser.2010.06.014

36. Singh, M., Shukla, R., Das, K., 2013. Harvesting of Microalgal Biomass. Biotechnol. Appl. Microalgae Biodiesel Value-Added Prod. 77-88. https://doi.org/10.1007/978-3-319-12334-9_5

37. Tchobanoglous, G., Burton, F.L., 1998. Ingeniería de aguas residuales: tratamiento, vertido y reutilización. McGraw-Hill.

38. U.S Department of Energy Fact sheet series, n.d. Combined Heat and Power Basics | Department of Energy [WWW Document]. URL https://energy.gov/eere/amo/combined-heat-and-power-basics (accessed 12.5.17). 


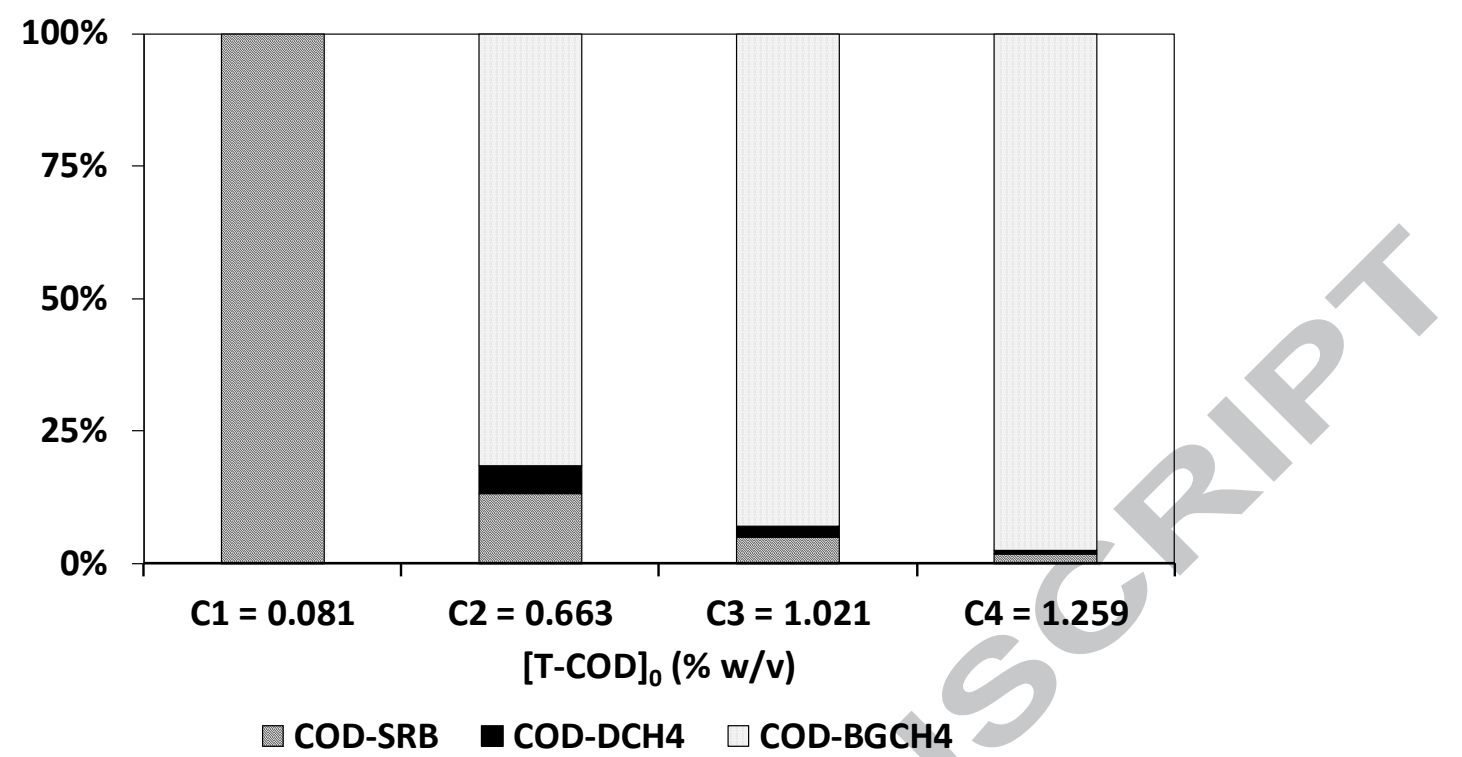

Figure 1. COD fate depending on the influent T-COD concentration ([T-COD $\left.]_{0}\right)$. COD-SRB: COD consumed by SRB; COD-DCH 4 : COD associated to dissolved methane; COD-BG $\mathrm{CH}_{4}$ : $\mathrm{COD}$ associated to methane in the biogas. 
$\diamond$-electric input $\quad \triangle$ electric output $\rightarrow$ NEED

(a)
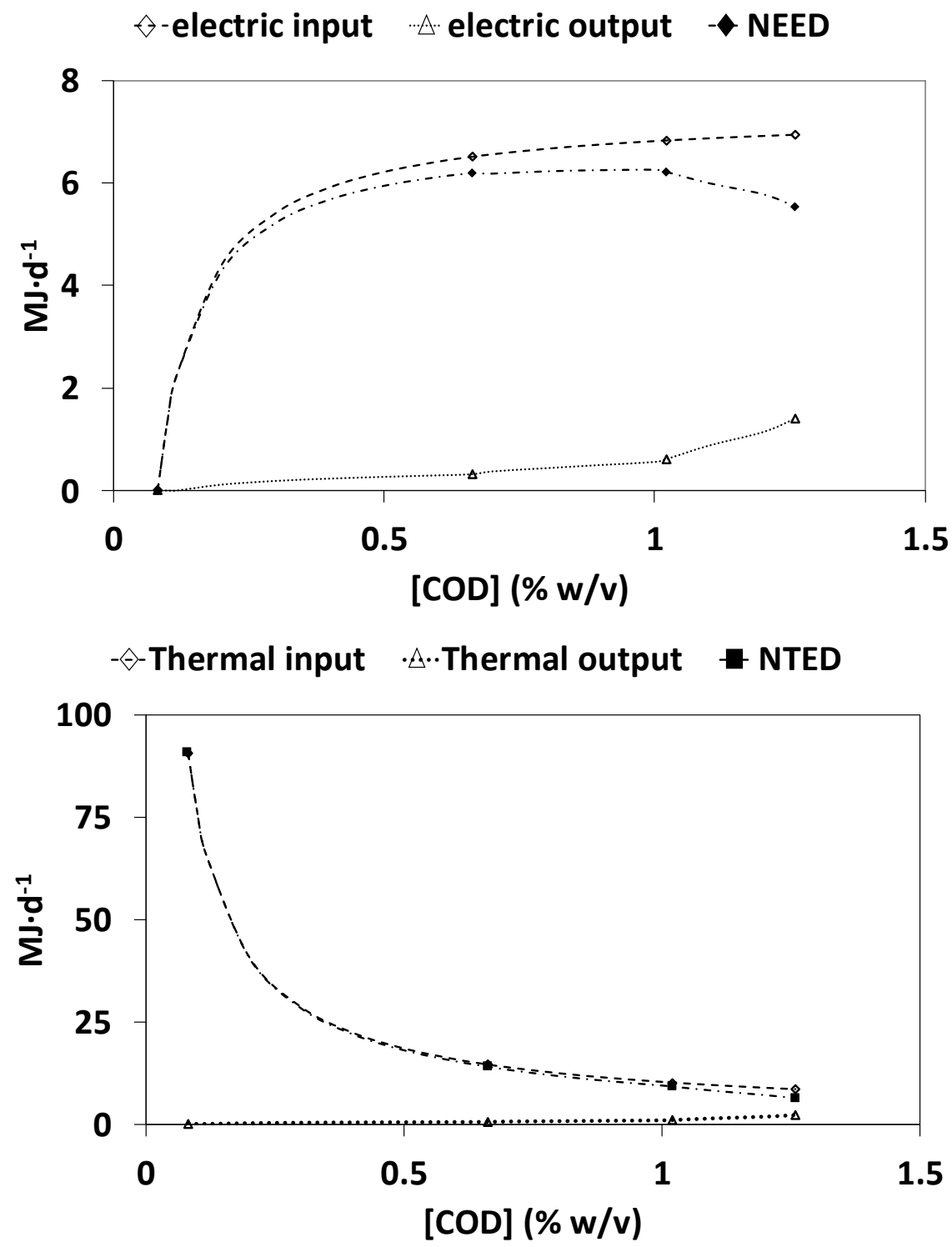

(b)

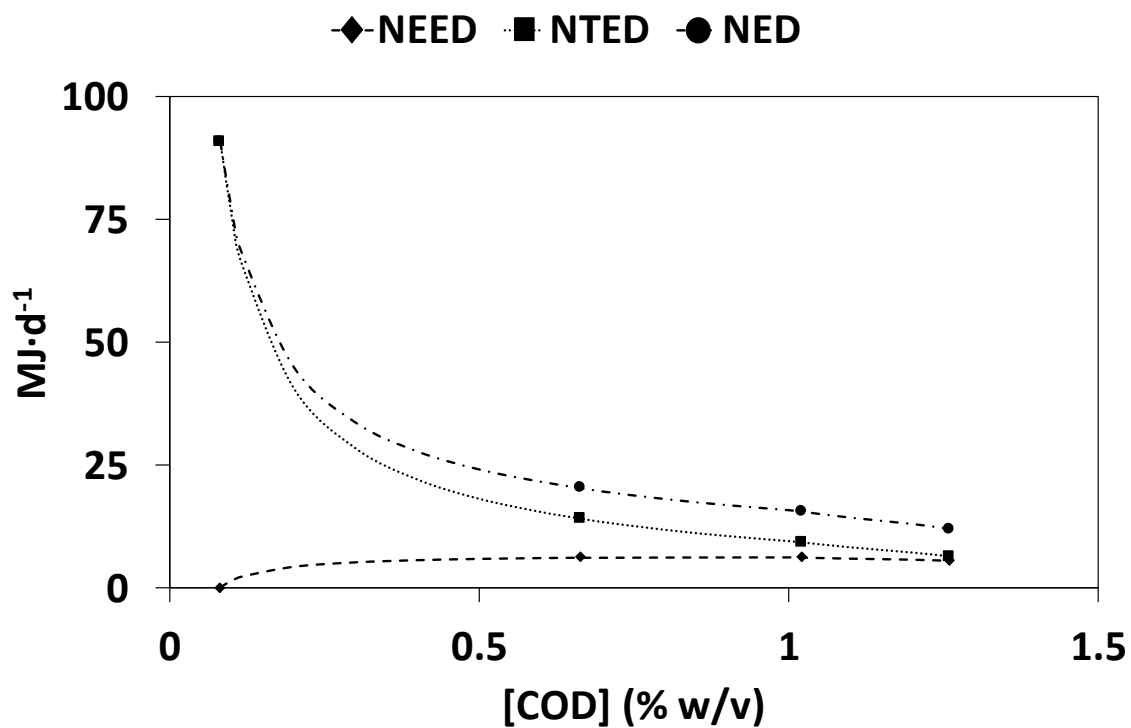

Figure 2. Electric (a) and thermal (b) energy balance assessment, and energy requirements (c). NEED: Net Electric Energy Demand; NTED: Net Thermal Energy Demand; NED: Net Energy Demand. 


\section{$\rightarrow$-Electric Efficiency - Thermal Efficiency - Energy Efficiency}

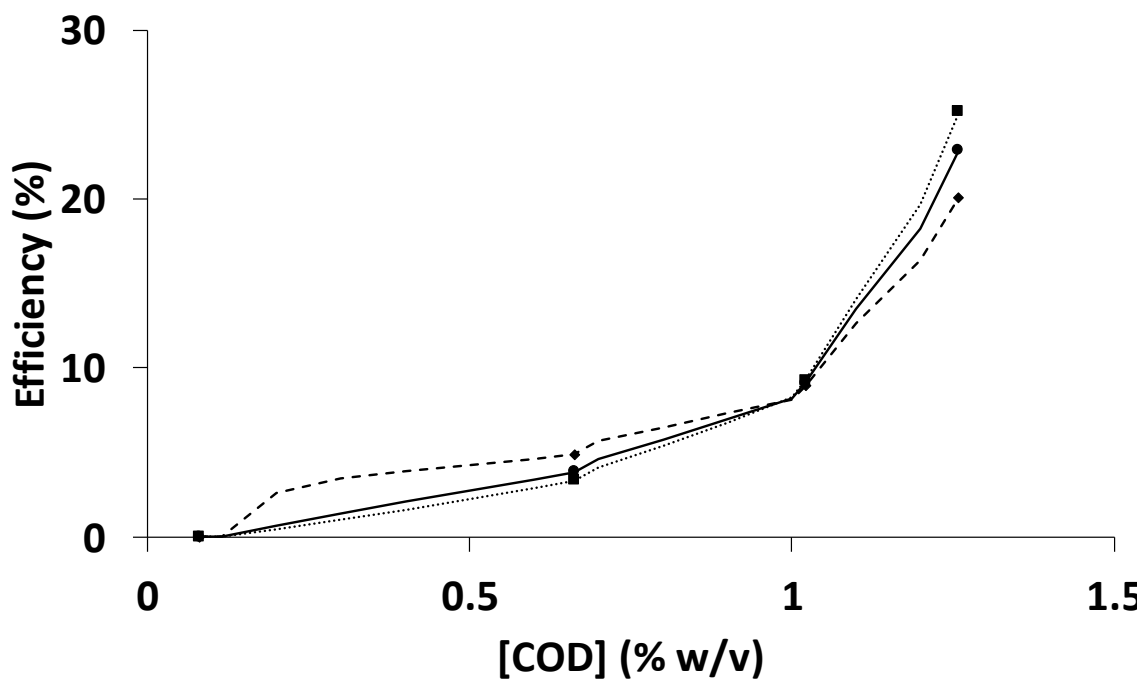

Figure 3. Electric, thermal and overall energy efficiencies. 
Table 1. Microalgae biomass samples characterisation (Mean \pm SD).

\begin{tabular}{|c|c|c|c|c|c|}
\hline \multirow{2}{*}{ Parameters } & \multirow{2}{*}{ Units } & \multicolumn{4}{|c|}{ Samples } \\
\hline & & $\mathrm{C} 1$ & $\mathrm{C} 2$ & C3 & C4 \\
\hline Sampling time & hours & 0 & 10.28 & 10.85 & 11.05 \\
\hline viability & $\%$ & $89.0 \pm 7.5$ & $85.1 \pm 8.5$ & $79.5 \pm 6.1$ & $38.1 \pm 10.7$ \\
\hline Biodegradability & $\%$ & $9.3 \pm 8.3$ & $14.2 \pm 8.3$ & $24.2 \pm 8.4$ & $52.8 \pm 8.3$ \\
\hline TS & $\mathrm{mg} \mathrm{TS} \cdot \mathrm{L}^{-1}$ & $1678 \pm 11$ & $5517 \pm 17$ & $8001 \pm 40$ & $9871 \pm 10$ \\
\hline VS & $\mathrm{mg} \mathrm{VS} \cdot \mathrm{L}^{-1}$ & $691 \pm 14$ & $4305 \pm 25$ & $6657 \pm 41$ & $8430 \pm 19$ \\
\hline $\mathrm{T}-\mathrm{COD}$ & $\mathrm{mg} \mathrm{O}_{2} \cdot \mathrm{L}^{-1}$ & $810 \pm 7$ & $6627 \pm 196$ & $10213 \pm 133$ & $12593 \pm 133$ \\
\hline S-COD & $\mathrm{mg} \mathrm{O}_{2} \cdot \mathrm{L}^{-1}$ & $210 \pm 16$ & $2033 \pm 34$ & $3137 \pm 111$ & $3750 \pm 62$ \\
\hline P-COD & $\mathrm{mg} \mathrm{O}_{2} \cdot \mathrm{L}^{-1}$ & $67.3 \pm 2.1$ & $45.6 \pm 1.8$ & $60.8 \pm 1.5$ & $61.2 \pm 1.8$ \\
\hline S-Pro & $\mathrm{mg} \operatorname{Pr} \cdot \mathrm{L}^{-1}$ & $20.2 \pm 0.6$ & $142.8 \pm 1.1$ & $260.1 \pm 7.1$ & $365.5 \pm 14.1$ \\
\hline P-Pro & $\mathrm{mg} \operatorname{Pr} \cdot \mathrm{L}^{-1}$ & $18.9 \pm 0.0$ & $24.4 \pm 1.9$ & $23.6 \pm 0.0$ & $26.5 \pm 3.2$ \\
\hline $\mathrm{P}-\mathrm{CH}$ & $\mathrm{mg} \mathrm{CH} \cdot \mathrm{L}^{-1}$ & $21.9 \pm 1.9$ & $5.6 \pm 0.3$ & $17.4 \pm 1.4$ & $15.0 \pm 1.6$ \\
\hline $\mathrm{S}-\mathrm{SO}_{4}$ & $\mathrm{mg} \mathrm{S} \cdot \mathrm{L}^{-1}$ & $7 \pm 2.3$ & $185.9 \pm 2.4$ & $182.2 \pm 2.2$ & $184.6 \pm 2.3$ \\
\hline
\end{tabular}


Table 2. Soluble/total COD and proteins-related COD fraction in the soluble phase, and concentration factors achieved for $\operatorname{COD}\left(\mathrm{F}_{\mathrm{COD}}\right)$, proteins $\left(\mathrm{F}_{\mathrm{PRO}}\right)$ and total sugars $\left(\mathrm{F}_{\mathrm{CH}}\right)$ with regard to the fresh microalgae culture.

\begin{tabular}{ccccccc}
\hline \multirow{2}{*}{ Sample } & $\frac{S-C O D}{T-C O D} \frac{S-C O D_{\text {Pro }}}{S-C O D}$ & & & \\
& \multicolumn{2}{c}{$\%$} & & & \\
& & & & & \\
& & & & & \\
C1 & $25.9 \pm 2.2$ & $23.1 \pm 2.5$ & - & - & \\
C2 & $30.7 \pm 1.4$ & $17.1 \pm 0.4$ & $8.3 \pm 0.8$ & $7.1 \pm 0.3$ & $11.5 \pm 2.1$ \\
C3 & $30.7 \pm 1.5$ & $20.1 \pm 1.3$ & $12.5 \pm 1.5$ & $12.9 \pm 0.7$ & $15.9 \pm 3.2$ \\
C4 & $29.8 \pm 0.8$ & $23.7 \pm 1.3$ & $15.2 \pm 1.5$ & $18.1 \pm 1.2$ & $20.3 \pm 2.8$ \\
\hline
\end{tabular}


- Cross-Flow Filtration (CFF) affected microalgae cell-wall integrity.

- Biodegradability of microalgae biomass was dependent on cell-wall integrity.

- Biomass solubilisation was related to a stress-induced release of organic polymers.

- A net energy demand was found for CFF regardless of the concentration achieved.

- Electricity demand was lower than heat demand for COD concentrations below $1 \%(w / v)$. 